\title{
Itinerant anthropologist exploring pathways of global crime
}

\author{
Anton Blok
}

Published online: 23 January 2010

(C) The Author(s) 2010. This article is published with open access at Springerlink.com

\section{Global outlaws. Crime, money, and power in the contemporary world}

By Carolyn Nordstrom (Berkeley: University of California Press, 2007, pp. 234, Paperback).

In the early 2000s, anthropologist Carolyn Nordstrom explored "invisible (illegal) realities of global flows" to write a new kind of ethnography that "can convey the roiling complex realities of the twenty-first century" (p. xi). The author spent three of the first five years of this century investigating on foot the pathways of global outlaws. Research in a variety of frontier locations took her from former war zones in Angola to major waterfronts in Los Angeles/Long Beach and Rotterdam. She observed, listened, and talked to hundreds of people on both sides of the law, finding her feet with the natives in the blurred borders between the legal and the illegal (for which she coins the term "il/legal") before sitting down and writing her case studies to "illuminate the universe of thought and action that falls beyond the scope of the legal" (p. xxi). The result of this ethnographic itinerary is an original and daring book that takes the reader straight to her adventurous encounters. Even if necessarily impressionistic, verging on the sensational, and emphasizing a journalistic style of reporting over analysis, the book questions received wisdom about global trade and transport. As the author succinctly puts it, her "examples are not the exception to the rule of economy. They are the economy" (pp. 23-24).

Nineteen brief chapters, "each devoted to a site along a continuum from the decidedly local to the vast transnational interrelationships defining the global market" (p. xix), provide the reader with lifelike vignettes of people and practices in a "shady" world. Nordstrom's itinerant fieldwork shows how and why extralegal networks are intimately intertwined with legal institutions around the world-not only in war torn postcolonial settings, but also close to home.

\footnotetext{
A. Blok $(\bowtie)$

Department of Anthropology, University of Amsterdam, Amsterdam, The Netherlands e-mail: anton.blok@xs4all.nl
} 
Observing and talking with her hosts mostly off the record, the author easily moves between widely different locations and situations, all of them linked to global networks of trade and transport, all of them associated with fraud, bribes, and outright theft. Nordstrom applies her category outlaws as easily to former Angolan warlords and their retainers, who have virtually taken over the state together with its precious resources (including diamonds, oil, and timber) and run the country as a patrimony or "family," as local people of different backgrounds euphemistically call it - as to smugglers of precious metals in Angola and lawbreakers at the seaport of Rotterdam, where customs officials fail because the very bulk of containers shipped makes checking many of them delay deliveries and kill business: customers would turn to other ports like Antwerp or Hamburg. As a Chamber of Commerce official Nordstrom interviewed phrased the dilemma, "If we want to stay the number one port, we have to deliver. So what happens if we hold up these shipments for inspection?" (p. 187).

Anticipating her chapter on the Dutch example (pp. 157-67), Nordstrom notes, "As I sit watching the 446 cargo ships enter and leave the mega-port of Rotterdam a day, I know I am watching somewhere between 200 and 446 ships breaking the law in some way. By most estimates I have received in these 5 years, it is more along the lines of 446. In the world today, this is called crime. Most of these ships are well respected, most carry commodities from well-respected corporations. Some are world leaders. While this is formally called crime, it usually is not called anything at all. Or perhaps it is just called business" (p. xvi). Without additional evidence about the contents of the shipping, the reader has to take Nordstrom's word for it. What may justify application of the term "outlaws" (and kindred terms in the literature on corruption) to widely different people and situations is their participation in extralegal global networks of trade and transport. But this does not solve all the problems of using terms fraught with so many implications.

Significantly, as Nordstrom's book makes clear, few of her global outlaws, though acknowledging illegal operations are very explicit about let alone particularly proud of their involvement in clandestine networks. Their attitude attests to the pragmatism of the survivor in an unfriendly and insecure environment. Nordstrom's informants involved in "extralegal," "informal," "shady" dealings talk about their practices in oblique terms, refering to it as "business," justifying it, and preferring to remain anonymous. As the author puts it in the first sentence of her book: "Acknowledgments in a book about outlaws are not easy. The more someone has helped, the greater the likelihood they would prefer their name not appear in print" (p. xi). Yet in her conclusion, the author fails to recognize an obvious aspect of the evidence she has amply documented in her book and summarized in its very title when she notes, "The vast majority of those who participate in the extra-legal do not think of themselves as criminals, as smugglers, as 'really' breaking the law. In their perspective, states being 'somewhat' important, are only somewhat noticed, somewhat respected. Vast extra-state economic networks are equally, and sometimes more, important..." (p. 207). With all the refreshing daring of her fieldwork and reporting on the "il/legal," Nordstrom's concluding statement neglects the numerous justifications she recorded when talking to outlaws. Her statement also plays down her recorded facts of theft of a nation (Angola), the usurpation and sale 
of a country's core resources, the abandonment and exploitation of people like the Marlboro-vending war orphan, the paradigmatic protagonist of the first chapter (to whom the book is dedicated) who tries to make a living in a war zone, and the evicted peasants who are relocated to their former land to work for the new owner: the "Gov'ner" - an economic and political entrepreneur, who controls the courts, the land registry, the land, the labor force, and development aid (pp. 3-9, 27-35). To drive her point home, Nordstrom refers to a report from Global Witness that estimates that more than $\$ 1$ billion a year disappears from oil revenues into the pockets of leading political figures in Angola:

This flow of government revenues into private hands carries a simple word: corruption. The term both clarifies and obscures a good deal of the reality of global money flows. Analyses of corruption generally stop at the national level. In truth, corruption is about transnational profiteering-it entails a highly cosmopolitan, twenty-first century form of international warlordism.... It's not just the story of bleeding a country. It's about owning it. This is a fact that even the poorest of locals recognize, perhaps more clearly than international analysts. A woman administrator, a businessman, and a poor peasant told me the same thing (here I use the words of the administrator):

You must appreciate that more than anything it's the family that explains this best. The whole country follows the model of a family. Control of the family rests in the hands of parents overseeing the resources, and they make decisions for everyone in their care. The political and military leaders of the country hold this position, a position they have created. Nothing happens without their knowledge or express permission. Everything coming into or out of the country moves with their blessings. No decision can be made without their approval. The family follows the lead of the parent, the country that of the model of the family. Parents don't squander resources, they control them.

This image of taking care of a 'family' — of running a familial countryprovides a justification for those feeding at the national trough. In my experience, few people see themselves as morally compromised. From torturers to criminals, from corrupt elites to wildcat profiteers, people devise explanations that smooth their actions into acceptability (pp. 58-59).

Nordstrom presents interviews with a military commander, a politician, and a businessman to illustrate her point. Each character in these stories provides justifications and rationalizations to "explain" their multiple deals in the usual clichés: for the good of my country, providing work and jobs (pp. 59-62).

Yet if so many different people do not see themselves as morally compromised, why do they need a front and go out of their way to justify their practices and try to hide them?

In the management and exploitation of twenty-first century frontiers, and the rapid creation of powerful empires, Nordstrom sees modern versions of the robber barons of previous centuries (p. 35, 57ff). Rather than mere stories of warlordism, they "represent modern-day empires in the same sense that the Carnegies, 
MacArthurs, and Stanfords viewed them. Behind the European villas and offshore accounts, the truly enterprising amass land and industries, transport routes, and monopolies over core commodities and service sectors" (p. 62). I am not sure if the qualification "robber barons" with the explicit references to the American experience is appropriate to make sense of the practices of warlords who took over the state, run the country as a "family," and "control" (i.e., squander) its resources (p. 59). Nordstrom's descriptions recall the older, original German meaning of the term: medieval lords subsisting by robbery, holding for ransom, or exorbitantly taxing travelers and traders passing through their domains situated below their river-side castles along Rhine and Elbe. Kleist's famous eponymous story of the horse-dealer Michael Kohlhaas (based on a sixteenth-century chronicle) remains a most vivid and memorable description of the habitus and practices of a latter-day Raubritter.

Stretching the term "robber barons" follows a once popular and sensational trend that obscures historical differences at the cost of analysis and understanding. The so-called robber barons of the late nineteenth and twentieth centuries "whose names now grace the large corporations and leading philanthropic organizations of the world" (p. 35) were quite different from both earlier Raubritter and present-day international warlords, including the economic and political entrepreneurs in Angola who, in the words of Nordstrom, own and dissipate an entire country, freely disposing over its resources, including land, labor, timber, and minerals (pp. 37-44, 57-59). These squandering practices form a glaring contrast with the multiple investments of captains of industry in America's infrastructure (rail-road, telegraph), industry (coal, steel, oil), management, education, art, and scienceall major innovations that made the USA (still considered until 1900 a "periphery" with respect to Western Europe) the foremost economy and world power in the twentieth century. Several break-through studies of the subject, most notably Alfred Chandler's influential The Visible Hand (1977), rendered the denomination "robber barons" for key figures like Carnegie, Stanford, Rockefeller, and MacArthur in the industrial and managerial revolution inadequate and obsolete. ${ }^{1}$

This brings us to another comment on Nordstrom's fascinating book. It is quite likely that well-respected ships and well-respected corporations (to which she briefly refers with some disparagement), precisely because they are respected, have a reputation to lose. This holds all the more because the expansion of corruption also invites the fight against it. Since the early 1990s, the independent organization Transparency International publishes its yearly Bribe Payers Index, Global Corruption Barometer, and Corruption Perception Index. These are lists of the most corrupt countries, corporations, and state officials. Moreover, in 1997, the OECD (Organization for Economic Co-operation and Development) drew up a "Treaty against Corruption" that thirty-seven countries have ratified. The United Nations boasts a Convention against corruption (UNCAC), the World Bank investigates corruption, and the European Union has a special office (OLAF) that controls its own integrity as well as the degree of corruption of new member States. This is not all. In 2004, no less than 120 international corporations united at the

\footnotetext{
1 See Richard R. John's valuable discussion of Chandler's book and its reception history (John 1997).
} 
World Economic Forum in Davos, Switzerland, in the Partnering Against Corruption Initiative (PACI), to resist paying bribes. A whole industry has developed around the fight against bribes. But does it help? According to the Swiss jurist Mark Pieth, professor of criminal law at Basel University and president of the Working Group on Bribery of the OECD (a group of thirty wealthy industrial countries that propagate democracy and market economy), these organizations do have an effect. He mentions the example of Siemens, the German electronics corporation that paid for years in more than fifty countries 1.3 billion euros in bribes, also to the Nigerian dictator Sani Abacha personally. The federal state of Bayern-Württemburg was shocked when the case was discovered and a thorough investigation of the illegal Schwarze Kassen led, in December 2008, to a deal with the public prosecutor in Munich. Siemens was fined 395 million euros and avoided appearing in court. Siemens bought off a similar investigation in the United States the same month and paid a fine of 800 million dollars. As Pieth notes, "For us, Siemens is a success story. In 1999, Germany accepted a new anti-corruption law based on the OESO treaty against bribery.... Imagine what Siemens means in Bayern. It is a miracle that the German authorities dared tackle a corporation that employs half of the region's population. More than fifty corruption cases are now running in Germany, but Siemens is the biggest case. This scandal caused a shock in international trade and industry." 2

Nordstrom's book omits the fight against transnational corruption. It is passed over in silence. This is unfortunate because as students of corruption point out, the first step in the fight against corruption is made when many people consider a given act improper. A distinctive characteristic of corruption is "moral condemnation," that is, when many people detect it and give it a name (Ledeneva 1998, 42-44). This analytical point about the discourse and epistemology of corruption is pertinent to Nordstrom's views and agenda. Throughout her long itinerary, the author considers global corruption or the interplay between legal and extralegal, as invisible. Nordstrom argues that it will remain invisible_-hence inevitable_-as long as people lack the conceptual tools to see and come to grips with it (p. 208).

The author should be credited for crafting such tools in her spirited experiment with new forms of ethnographic fieldwork and ethnographic writing. Her approach leads to better insight in what she calls "the pas de deux of the il/legal" - a common practice of using public offices and resources for private advantage. Since Max Weber, we know that such practices are not always widely perceived as corruption, particularly if an individual making personal gains is simultaneously making a positive contribution to society, that is, their own moral community. We note its rhetoric among Nordstrom's informants: they justify and mask what we call extralegal or illegal practices when insisting that their operations are serving their country-or clientele: more work and jobs, better education, rebuilding infrastructure and communications. If they do not consider themselves "outlaws," as Nordstrom argues, what justifies our use of this term and its kindred expressions, including "illegal," "extralegal," "crime," "criminal," "corruption," "fraud," and

\footnotetext{
${ }^{2}$ For this passage on the international fight against corruption I have drawn on newspaper accounts, in particular on Laura Staring's discussion (2009).
} 
"bribery"? The notion of "outlaw" suggests the presence of a law and of a state that at least tries or pretends to maintain a legal order. An outlaw is by definition a person who is excluded from protection by the law. If politicians are the law, however, as is the case in Angola where nothing happens without their approval, the term "outlaw" and its entire kindred vocabulary are problematic. Uncritical usage means reading another culture through distorted glasses. Can there be outlaws in lawless regions? As experts on corruption point out, western definitions of corruption can be very misleading when applied to other societies (Ledeneva 1998, 44).

With the development of nation states and their claim to a monopoly over the means of violence and taxation, the pejorative term "corruption" (from Lat. corruptus, broken in pieces, putrefactive decay, and rottenness) was adopted to refer to all infractions of that monopoly. Thompson (1975) describes an exemplary development in early modern England when hunting became poaching with the advent of the enclosures. As the executive director of Marine Exchange in Southern California, which oversees the radar surveillance of all ships entering and leaving the Los Angeles/Long Beach port areas, reminded Nordstrom, "Ports were never designed to be secure. Indeed, as nodal points of trade, they function best when truly open" (pp. 197-98).

Ironically, the practice of justifying and hiding extralegal operations, amply documented in Nordstrom's book, provides tell-tale signs that indicate a salient aspect of corruption: the tacit acknowledgment that certain acts are improper. In Global Outlaws, however, people recognize "il/legal" practices, but downplay, mitigate, hide, justify, and explain them away. If they were invisible, as Nordstrom argues, her rich and painstaking record of the evidence would contradict her. Qui s'excuse, s'accuse.

Open Access This article is distributed under the terms of the Creative Commons Attribution Noncommercial License which permits any noncommercial use, distribution, and reproduction in any medium, provided the original author(s) and source are credited.

\section{References}

Chandler, Jr., and D. Alfred. 1977. The visible hand: the managerial revolution in American business. Cambridge, MA: Harvard Belknap.

John, R.R. 1997. Elaborations revisions, dissents: Alfred D. Chandler, Jr.'s, The visible hand after twenty years. Business History Review 71: 151-200.

Ledeneva, A.V. 1998. Russia's economy of favours. Blat, networking, and informal exchange. Cambridge: Cambridge University Press.

Staring, L. 2009. Vals spel zonder grenzen: Globalisering maakt de strijd tegen corruptie moeilijk [Fraud without frontiers: Globalization makes fighting corruption difficult]. NRC Handelsblad. 21 February.

Thompson, E.P. 1975. Whigs and hunters. The origin of the Black Act. London: Allen Lane. 